\title{
The V4: a Decade after the EU Entry
}

\author{
Eduard Nežinský, Elena Fifeková
}

\begin{abstract}
A B S T R A C T
Objective: The objective of the paper is to give a picture of the sources of economic growth in the V4 countries during the decade following their EU entry and to crosscheck the results obtained by parametric and non-parametric approaches. Growth accounting technique is used to depict dynamics of the V4 countries evolution since 1995 up to 2013. The poor post-crisis performance reflected in TFP indicator is in line with the result of the absence of technological progress obtained by data envelopment analysis.
\end{abstract}

Research Design \& Methods: Sources of the economic growth are identified by growth accounting based on Solow-Swan model. Non-parametrical part employs an SBM measure of efficiency in Data envelopment analysis as an application of linear programming optimization.

Findings: Main findings include determining faster-than-average economic growth of the V4 followed by a considerable decline both in total factor productivity and in catching-up rate in the after-crisis period. DEA approach reveals excessive use of labor in all of the V4 countries and finds almost negligible technological change.

Implications \& Recommendations: The main concern for economic policy in the V4 as well as the entire EU continues to be tackling unemployment and facilitating factors' productivity by structural reforms.

Contribution \& Value Added: The paper makes use of parametric and non-parametric approaches with a view to cross-checking the results obtained on the technological change within the EU at large and across the V4 countries in particular.

Article type: original research paper

Keywords: growth accounting; catching-up rate; data envelopment analysis; Malmquist productivity index

JEL codes: $\quad$ E23, C61, O47

Received: 2 February $2014 \quad$ Revised: 22 March $2014 \quad$ Accepted: 15 May 2014

The paper was prepared within projects VEGA 1/0906/12 "Technological change, catch-up and ecoefficiency: growth and convergence in EU countries" and VEGA 1/0795/12 "The extended Leontief model with structural decomposition with the application on Slovak economy".

\section{Suggested citation:}

Nežinský, E., \& Fifeková, E. (2014). The V4: a Decade after the EU Entry. Entrepreneurial Business and Economics Review, 2(2), 31-46. 


\section{INTRODUCTION}

The economies of the Visegrad Four (V4) and the Baltic states belonged in the past ten years to those fastest growing within the EU, reaching their highest real economic growth rate in the time term between their EU accession and the outbreak of the crisis, i.e., in the years 2004-2008. During that time span, the V4 average real growth rate was higher than that of the EU15 by over 1 percentage point.

One of the main factors contributing to the high economic growth in the V4 was increase in foreign investments as the region had become an attractive destination for foreign capital. Liberalization of the capital and financial accounts heightened the financial integration of the aforementioned countries, and the fulfilment of the real convergence criteria following the EU entry further increased the attractiveness of the region for foreign investors, along with their confidence in the Group's sound economic development. Thus, room was created for technological and innovation catching-up processes with the "old" EU members, which, in turn, accelerated economic growth and facilitated narrowing of the performance gap.

Besides showing the role of the foreign direct investment in the capital stock growth, growth accounting based on the Solow-Swan model may be applied in order to identify the sources of economic growth in V4 as well as across other European Union member states.

The parametrical way is though challengeable where it comes to the assumed form of the production function that describes transformation of inputs into the output. While another assumption-of returns to scale-lends itself well to incorporation into the basic Solow model, the Cobb-Douglas form remains untouchable. The question begs itself whether giving up the explicit form of the transformation function would make a qualitative difference to the results produced by the parametric approach. In order to carry out such type of analysis, an approximation of the production possibility set is constructed as linear combinations of best practice - efficient - units under examination. A piecewise boundary line that represents technology is called empirical frontier since it is formed from observed units though at the expense of not treating possible statistical noise in data. To assess a change in performance over time, two frontier lines relating to different time periods can be constructed and compared. Given the Cobb-Douglas function was a good representation of the transformation function, the results produced by the two approaches should be qualitatively comparable in such an intertemporal setting.

\section{LITERATURE REVIEW}

Classical approach to productivity analysis, which dates back to the seminal work of Solow (1957), provides a powerful analytical tool for determining sources of economic growth. Growth accounting has been then used in a massive body of studies, e.g. Romer (1990) and Barro (1996), to mention well-known macro analyses. The method is being used in contemporary studies of the European Commission (2008; 2009; and 2012), OECD, International Monetary Fund (Schadler et al., 2006), ECB (Proietti \& Musso, 2007), World Bank, or the U.S. Bureau of Labor Statistics. 
FDI inflow has been identified as an important determinant of growth in the new EU member states (NMS) in a number of studies including investigating the characteristics and relationship of FDI in Central and Eastern European countries by Witkowska (2007) and in V4 countries in particular in Babunek (2012).

Productivity analysis that employs non-parametric approach is traceable back to Farrell's work (1957) which presented the first empirical application of the entirely conceptual approaches to efficiency by Pareto and Koopmans. The modern version of data envelopment analysis (DEA) originated in Charnes et al. (1978), where the first model, lately named CCR, was introduced. The later theoretical developments addressing the problem of weak efficiency were closely related to Tone's works introducing slack-based measure of efficiency (Tone, 2001) with the most recent application in evaluating economic and environmental efficiency in Chang et al. (2014). Intertemporal analysis utilizing distance functions and Malmquist index in a multi-output setting was introduced by Fare et al. (1996). In Yörüka \& Zaimb (2005) the productivity of OECD countries was explored employing intertemporal DEA model, Eslami \& Khoveyni (2014) use Malmquist index to assess units in banking sector.

\section{MATERIAL AND METHODS}

\section{Growth Accounting and Catch-up}

The standard analytical tool is based on the Cobb-Douglas production function

$$
Y=A K^{\alpha} L^{1-\alpha}
$$

where:

$$
\begin{aligned}
& Y \text { - total output (GDP, value added), } \\
& K \text { - capital, } \\
& L \text {-labor, } \\
& \alpha \text { - capital's share of income, } \\
& 1-\alpha \text {-labor's share of income. }
\end{aligned}
$$

Production function enables to decompose growth rate of the total output into contributions attributable to capital, labor, and technological change (total factor productivity, A)

$$
Y=A F(L, K)
$$

Rearranging, taking logs and derivatives with respect to time yields

$$
\begin{aligned}
& g(Y)=g(A)+\frac{\frac{A F_{K} K}{Y}}{g(K)}+\frac{\frac{A F_{L}}{Y}}{L} \\
& g(Y)=g(A)+\frac{\frac{A F_{K} K}{Y}}{g(K)}+\frac{\frac{A F_{L} L}{Y}}{g(L)}
\end{aligned}
$$

where:

$A F_{K} K / Y$ - capital's share of total income, $\alpha_{t}$

$A F_{L} / Y$ - capital's share of total income, $1-\alpha_{t}$ 
Total factor productivity growth rate $\mathrm{g}(\mathrm{A})$ can be expressed as:

$$
g(A)=g Y-\alpha_{t} g(K)-\left(1-\alpha_{t}\right) g(L)
$$

It follows from (5) that total factor productivity growth rate presents a difference between the output growth rate and the weighted sum of growth rates of capital and labor, weights being capital and labor elasticities of output.

Following the European Commission (2008), we define the catch-up rate as the average percentage change of the performance gap among particular countries.

$$
M=100 \frac{\Delta\left(Y_{i t}-Y_{t}^{*}\right)}{\left(Y_{i t-1}-Y_{t-1}^{*}\right)}
$$

where:

$M$ - catch-up rate,

$Y_{t}^{*}$ - average $Y_{t}$ value for EU15,

$\Delta$ - the absolute variation between $t$ and $t-1$, where $Y_{t}^{*}$ is weighted average of EU15,

$Y_{i t}$ - the level of index of GDP per capita in PPS terms for country $i$ at time $t$,

Negative catch-up rate means that the performance gap between the catching-up country and the EU15 average is narrowing, while a positive catch-up rate means widening of the gap.

\section{DEA Models}

The neoclassical approach finds itself competed by non-parametric frontier analysis. This approach represented by DEA (data envelopment analysis) is a generalpurpose quantitative method for assessing performance applicable to units of assessment such as retails outlets, hospitals, bank branches on the micro level or as economies as whole constituting individual units of assessment.

In formal analysis, each unit under evaluation is called DMU - Decision Making Unit, the total number of DMUs being $n$. DMU is assumed to transform $m$ inputs into generally $s$ outputs. Unlike in the case of production function approach, DMUs are not assumed to perform at their best, thus one can evaluate efficiency of transforming inputs into outputs and form a production possibility set frontier from efficient units. Organizing inputs and outputs data in matrices, one obtains input matrix $\boldsymbol{X}$ and output matrix $Y$, element $x_{i j}$ meaning amount of input $i$ used by DMU $j$ and element $y_{r j}$ meaning amount of output $r$ used by DMU $j$.

$$
X=\left[\begin{array}{cccc}
x_{11} & x_{12} & \ldots & x_{1 n} \\
x_{21} & x_{22} & \ldots & x_{2 n} \\
\cdot & \cdot & \ldots & \cdot \\
x_{m 1} & x_{m 2} & \ldots & x_{m n}
\end{array}\right], \quad Y=\left[\begin{array}{cccc}
y_{11} & y_{12} & \ldots & y_{1 n} \\
y_{21} & y_{22} & \ldots & y_{2 n} \\
\cdot & \cdot & \ldots & \cdot \\
y_{m 1} & y_{m 2} & \ldots & y_{m n}
\end{array}\right]
$$

In DEA model, an optimization problem is solved by each DMU, constraints describing the production possibility set and objective function measuring distance from the frontier. In our analysis, we use SBM measure of efficiency (Tone, 2001) defined by the following fractional program: 


$$
\begin{array}{ll}
\min _{\lambda, s^{+}, s^{-}} \rho & =\frac{1-\frac{1}{m} \sum_{i=1}^{m} s_{i}^{-} / x_{i 0}}{1+\frac{1}{s} \sum_{r=1}^{s} s_{r}^{+} / y_{r 0}} \\
\text { s.t. } \quad & x_{0}=X \lambda+s^{-} \\
& y_{0}=Y \lambda-s^{+} \\
\lambda & \geq 0, s^{-} \geq 0, s^{+} \geq 0
\end{array}
$$

The program (7) can be linearized and solved yielding optimal solutions for $s^{+}, s^{-}$, and $\lambda$. In order to give the model input orientation, penalization for non-zero slack variables in the denominator shall be dropped off, taking the following form.

$$
\begin{array}{ll}
\min \rho= & 1-\frac{1}{m} \sum_{i=1}^{m} s_{i}^{-} / x_{i 0} \\
\text { s.t. } & x_{0}=X \lambda+s^{-} \\
& y_{0}=Y \lambda-s^{+} \\
& \lambda \geq 0, s^{-} \geq 0, s^{+} \geq 0
\end{array}
$$

Non-zero optimal solutions for $\lambda$ determine set of indexes which correspond to efficient DMUs forming efficiency frontier (with a zero distance from the boundary) for which $\rho=1$ holds as well as $s^{+}=0$ and $s^{-}=0$.

The term $\frac{1}{m} \sum_{i=1}^{m} s_{i}^{-} / x_{i 0}$ in the objective function in (8) can be viewed as a penalization bringing the efficiency measure $\rho$ down beneath the unit. Thus can be slacks relative to the actual inputs $s_{i}^{-} / x_{i 0}$ interpreted as relative contributions of corresponding inputs to overall penalty. This way can relative importance of inputs in terms of efficiency be determined. Intertemporal analysis can be carried out employing Malmquist index (Färe et al., 1994)

$$
M I=C \times F=\frac{d_{i}^{2}\left(x_{0}, y_{0}\right)^{2}}{d_{i}^{1}\left(x_{0}, y_{0}\right)^{1}}\left[\frac{d_{i}^{1}\left(x_{0}, y_{0}\right)^{1}}{d_{i}^{2}\left(x_{0}, y_{0}\right)^{1}} \times \frac{d_{i}^{1}\left(x_{0}, y_{0}\right)^{2}}{d_{i}^{2}\left(x_{0}, y_{0}\right)^{2}}\right]^{1 / 2}
$$

where:

indexes 1, 2 correspond to periods 1 and 2,

$d_{i}$-efficiency measure (obtained by DEA program, $i$ stands for input orientation),

$x_{0}, y_{0},-$ activity of the $\mathrm{DMU}_{0}$ under consideration.

The two components, $\mathrm{C}$ and $\mathrm{F}$, can be assigned to catch-up effect meaning change of individual performance and $\mathrm{F}$ standing for frontier-shift effect describing change of technology.

We consider European economies as DMUs transforming inputs-capital and laborinto the output (GDP), one can therefore be interested in the efficiency measure of such a transformation process. Three SBM input oriented DEA models have been computed - two static models for endpoint years 2000 and 2013 and intertemporal model using both 2000 and 2013 data assuming constant returns to scale in all three models. 


\section{Data}

In the analysis, 26 European countries are included (27 EU member states as of 2013 less Luxembourg which has been excluded due to the outlying data). We use annual data on standard technical output proxied by gross domestic product $(\mathrm{Y})$ and inputs - capital (K) and labor (L). GDP at constant 2005 prices come from the Eurostat database as well as most of the data on labor force in the economy. Some missing data were supplemented from GDCC. UNCTAD database was used to collect data on FDI flows. Time series of estimated data on capital stock at 2005 prices come from AMECO EU database.

For growth accounting calculations, data span is 2000 through 2013. For data envelopment analysis we use endpoint 2000 and 2013 data.

\section{RESULTS AND DISCUSSION}

\section{Sources of the Growth of V4 Countries}

Rapid growth of the Visegrad Four can be illustrated by growth rates of the V4 countries compared to growth rates of EU27 and EU15. Table 1 depicts real growth rates.

Table 1. GDP growth rate in the years 1996-2015 (in \%, at 2005 prices, 2013-2015 estimations)

\begin{tabular}{|l|r|r|r|r|}
\hline \multicolumn{1}{|c|}{ Country } & \multicolumn{1}{c|}{$\mathbf{1 9 9 6 - 2 0 1 5}$} & \multicolumn{1}{c|}{$\mathbf{1 9 9 6 - 2 0 0 3}$} & \multicolumn{1}{c|}{$\mathbf{2 0 0 4 - 2 0 0 8}$} & \multicolumn{1}{c|}{$\mathbf{2 0 0 9 - 2 0 1 5}$} \\
\hline EU27 & 1.55 & 2.13 & 1.81 & 0.93 \\
\hline EU15 & 1.46 & 2.08 & 1.64 & 0.87 \\
\hline V4 & 3.08 & 3.15 & 4.05 & 1.83 \\
\hline Czech Republic & 2.22 & 2.02 & 4.49 & 0.87 \\
\hline Hungary & 1.84 & 2.97 & 1.76 & 0.79 \\
\hline Poland & 3.76 & 3.71 & 4.32 & 2.42 \\
\hline Slovakia & 3.59 & 3.31 & 6.19 & 2.15 \\
\hline
\end{tabular}

Source: own calculations based on data of Eurostat.

One of the main factors contributing to the high economic growth in the V4 was increase in foreign investments as the region had become an attractive destination for foreign capital. Liberalization of the capital and financial accounts heightened the financial integration of the aforementioned countries, and the fulfillment of the real convergence criteria following the EU entry further increased the attractiveness of the region for foreign investors, along with their confidence in the Group's sound economic development. Thus, room was created for technological and innovation catching up processes with the "old" EU members, which, in turn, accelerated economic growth and facilitated the narrowing of the performance gap. Table 2 illustrates the catch up rate of the V4 with the EU15.

The year 2009 marked the end of the catch up process in the Czech Republic and Slovakia, simultaneously revealing the low ability of the V4 countries to maintain the growth dynamics of the previous period. Only in Poland and Hungary, the pre-crisis levels of catching up managed to get picked up. As for Slovakia, even though the country still belongs to those striving to narrow the performance gap with the current levels of catching up, the dynamics of this process is now significantly weaker than in the precrisis time period. The slowdown of European growth, understandably, tends to undermine the earlier optimism about a reasonably quick catching up on behalf of the V4 
countries. The claim seems particularly relevant in the case of Slovakia where, given that the EU15 is Slovakia's main export market, the deceleration of the growth dynamics across the EU15 may result in Slovak exports decrease, bringing about, in the wake, a rapid drop in the country's economic growth as a whole.

Table 2. The catch up rate of the V4 with the EU15 in the years 1996-2012

\begin{tabular}{|l|c|c|c|c|c|}
\hline Country & $\mathbf{1 9 9 6 - 2 0 1 2}$ & $\mathbf{1 9 9 6 - 1 9 9 8}$ & $\mathbf{1 9 9 9 - 2 0 0 3}$ & $\mathbf{2 0 0 4 - 2 0 0 8}$ & $\mathbf{2 0 0 9 - 2 0 1 2}$ \\
\hline V4 & -2.45 & -1.67 & -1.28 & -3.12 & -3.68 \\
\hline Czech Republic & -1.07 & 3.13 & -2.42 & -3.59 & 0.61 \\
\hline Hungary & -1.86 & -1.28 & -3.41 & -1.14 & -1.27 \\
\hline Poland & -2.64 & -2.40 & -0.58 & -2.90 & -5.09 \\
\hline Slovakia & -3.54 & -2.36 & -1.37 & -7.50 & -2.17 \\
\hline
\end{tabular}

Source: own calculations based on data of Eurostat.

The standard method of growth accounting (Solow, 1957) enables examination of particular sources of growth (labor, capital, technology). Foreign direct investment (FDI) is generally considered to play an important role with regard to the impact of individual factors on economic performance. The need for extensive restructuring, with a view to boosting the competitiveness of individual segments across the V4 countries, entailed the fact that the investment requirements of the economies at issue highly exceeded their domestic savings opportunities, creating, thus, pressure to attract foreign funds. (FDI gradually became the principal source of financing current account deficits.) Consequently, not only did FDI influence the capital stock (through the gross fixed capital formation - see Table 3), but also favorably impacted the technological preparedness and productivity growth of the V4 economies.

Table 3. FDI inflow to V4 countries (percentage of gross fixed capital formation), 2000-2011

\begin{tabular}{|l|r|r|r|r|r|r|r|r|r|r|r|r|}
\hline Country & $\mathbf{2 0 0 0}$ & $\mathbf{2 0 0 1}$ & $\mathbf{2 0 0 2}$ & $\mathbf{2 0 0 3}$ & $\mathbf{2 0 0 4}$ & $\mathbf{2 0 0 5}$ & $\mathbf{2 0 0 6}$ & $\mathbf{2 0 0 7}$ & $\mathbf{2 0 0 8}$ & $\mathbf{2 0 0 9}$ & $\mathbf{2 0 1 0}$ & $\mathbf{2 0 1 1}$ \\
\hline EU27 & 40.1 & 22.3 & 17.1 & 12.8 & 8.8 & 18.2 & 19.2 & 23.8 & 14.1 & 11.6 & 12.6 & 13.5 \\
\hline Czech Republic & 29.4 & 30.8 & 39.1 & 8.2 & 16.8 & 34.6 & 14.3 & 21.3 & 10.6 & 6.0 & 12.6 & 4.5 \\
\hline Hungary & 24.5 & 31.6 & 19.3 & 11.4 & 18.4 & 30.7 & 27.9 & 13.3 & 18.9 & 7.6 & 9.2 & 23.2 \\
\hline Poland & 23.2 & 14.5 & 11.1 & 11.6 & 28.1 & 18.6 & 29.2 & 25.7 & 12.6 & 14.2 & 14.9 & 18.1 \\
\hline Slovakia & 51.5 & 37.6 & 87.1 & 36.0 & 39.7 & 24.4 & 39.1 & 20.4 & 20.8 & 0.0 & 9.1 & 9.9 \\
\hline
\end{tabular}

Source: UNCTADstat 2013.

Further, total net capital stock within the V4 countries was growing much faster than in the "old" member states, while Poland and Hungary experiencing the highest growth in the capital stock. Following 2008, however, the capital growth within the Group, except for Poland, slowed down. As for Slovakia and Hungary, during the crisis and post-crisis periods, the capital growth nearly ceased, in response to the decline in investment activities (Figure 1).

The relative FDI stock (FDI as a percentage of GDP) in the EU8 ${ }^{1}$ currently exceeds that of the "old" member states by 10.5 percentage point and in the V4 countries by 11 percentage points (Figure 2). Relative to GDP, FDI stock is the highest in Estonia (86.2\%) and Hungary (81.7\%). In Slovakia the FDI stock reaches $60.85 \%$ GDP.

\footnotetext{
${ }^{1}$ Czech Republic, Estonia, Hungary, Latvia, Lithuania, Poland, Slovakia, Slovenia.
} 


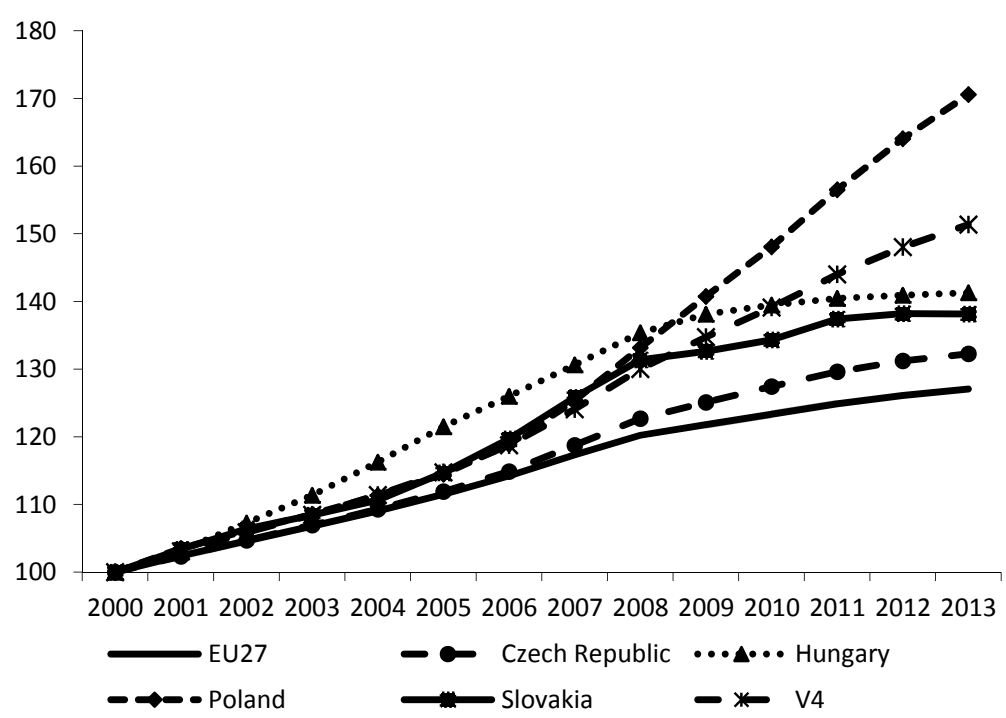

Figure 1. Net capital stock in the years $200-2013$ (year $2000=100 \%$, at 2005 prices) Source: own calculations based on European Commission (Ameco).



Figure 2. Foreign direct investment inflow in the years 1995-2010 (in \% of GDP)

*excluding Luxembourg

Source: own calculations based on UNCTAD.

Alongside FDIs, employment is closely related to economic growth, while being a matter of a broader social concern at the same time. The employment in the V4 countries (Figure 3 ) had already displayed a rather sluggish upward trend in the pre-crisis years, but currently, again with the exception of Poland, it even fails to reach the modest pre-crisis figures. Relative to other sources of growth, the employment growth rate across all the countries examined least affected the real GDP growth, but following the crisis, the employment rate influenced the GDP growth negatively. 


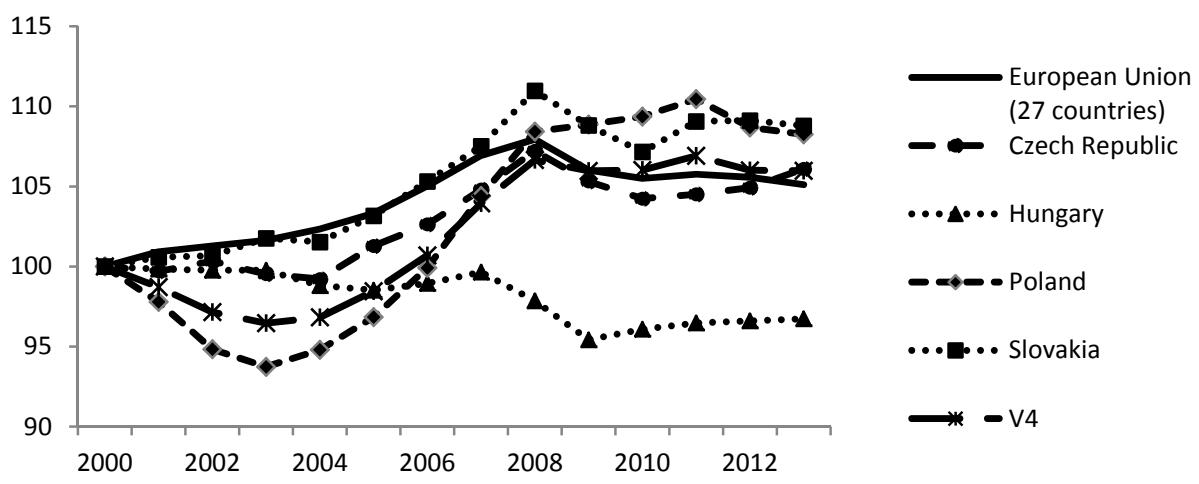

Figure 3. Employment rate dynamics in the years $2000-2012$ (year $2000=100 \%$ ) Source: own calculations based on Eurostat.

The slow rate of employment growth was across all the countries offset by the reasonably high rate of labor productivity growth, which stemmed from significant labor productivity gap with the "old" member states and from steady decrease in the technological backwardness of the V4 countries. Quite importantly in this respect, labor productivity experienced a hike, above all in Poland and Slovakia.

As far as long-term economic growth is concerned, it is particularly vital to monitor the effect of total factor productivity (TFP) on growth for it brings long-term growth effects, represents a permanent change in the rate of accumulation and, thus, permanent change in the rate of economic growth.

Table 3. Contribution of production factors to growth in the years 2000-2013 (average annual percentage change in constant prices)

\begin{tabular}{|c|c|c|c|c|c|c|c|c|}
\hline \multirow[b]{2}{*}{ Country } & \multicolumn{4}{|c|}{$2000-2013$} & \multicolumn{4}{|c|}{$2000-2003$} \\
\hline & GDP & $\begin{array}{l}\text { capital } \\
\text { factor }\end{array}$ & $\begin{array}{l}\text { labor } \\
\text { factor }\end{array}$ & TFP & GDP & $\begin{array}{l}\text { capital } \\
\text { factor }\end{array}$ & $\begin{array}{l}\text { labor } \\
\text { factor }\end{array}$ & TFP \\
\hline EU27 & 1.36 & 0.65 & 0.31 & 0.4 & 2.16 & 0.76 & 0.53 & 0.87 \\
\hline EU15 & 1.24 & 0.64 & 0.36 & 0.24 & 2.09 & 0.78 & 0.78 & 0.53 \\
\hline Czech Republic & 2.73 & 0.98 & 0.21 & 1.54 & 3.3 & 1.06 & -0.17 & 2.41 \\
\hline Hungary & 1.78 & 1.04 & -0.10 & 0.84 & 4.07 & 1.32 & 0.11 & 2.64 \\
\hline Poland & 3.65 & 1.89 & 0.21 & 1.55 & 2.69 & 1.26 & -1.26 & 2.70 \\
\hline Slovakia & 3.98 & 1.29 & 0.22 & 2.46 & 3.55 & 1.31 & -0.03 & 2.27 \\
\hline \begin{tabular}{|l|} 
V4 countries \\
\end{tabular} & 3.16 & 1.05 & 0.19 & 1.93 & 3.14 & 1.13 & -0.69 & 2.71 \\
\hline \multirow[b]{2}{*}{ Country } & \multicolumn{4}{|c|}{$2004-2008$} & \multicolumn{4}{|c|}{ 2009-2013 } \\
\hline & GDP & $\begin{array}{l}\text { capital } \\
\text { factor }\end{array}$ & $\begin{array}{l}\text { labor } \\
\text { factor }\end{array}$ & TFP & GDP & $\begin{array}{l}\text { capital } \\
\text { factor }\end{array}$ & $\begin{array}{l}\text { labor } \\
\text { factor }\end{array}$ & TFP \\
\hline EU27 & 2.33 & 0.84 & 0.78 & 0.71 & -0.24 & 0.38 & -0.35 & -0.28 \\
\hline EU15 & 2.13 & 0.82 & 0.73 & 0.58 & -0.32 & 0.35 & -0.34 & -0.33 \\
\hline Czech Republic & 5.47 & 1.24 & 0.83 & 3.39 & -0.46 & 0.65 & -0.10 & -1.00 \\
\hline Hungary & 2.73 & 1.52 & -0.24 & 1.45 & -1.01 & 0.34 & -0.14 & -1.21 \\
\hline Poland & 5.42 & 1.90 & 1.61 & 1.90 & 2.65 & 2.37 & -0.01 & 0.29 \\
\hline Slovakia & 7.26 & 2.05 & 0.83 & 4.37 & 1.03 & 0.51 & -0.19 & 0.71 \\
\hline V4 countries & 5.09 & 1.51 & 1.16 & 2.43 & 1.25 & 0.52 & -0.07 & 0.81 \\
\hline
\end{tabular}

Capital, labor - weighted rate of growth, where the weights are labor and capital product elasticity. Source: own calculations based on European Commission (Ameco). 
As can be seen from Table 3, total factor productivity was a significant long-term pro-growth factor. Its impact was the strongest in the Czech Republic and Slovakia, whereas less pronounced in Poland and Hungary. As with other factors, however, the influence of TFP on GDP growth varied in different time periods. The highest growth of total factor productivity was reached in 2004-2008, while in the post-crisis period the TFP growth rate started to cause a negative effect on GDP, especially in the Czech Republic and Hungary.

The economic crisis and its aftermath have inhibited the GDP growth as well as that of its factors. The European Commission projections assume that it is necessary to revise the potential product estimate downwards (averagely, for $2009-2060$, the potential GDP growth of $1.4 \%$ is expected).

\section{SBM efficiency measures}

The DEA approach was employed two ways - static analysis to identify sources of inefficiency and intertemporal analysis using Malmquist index. The computations consisted of solving 26 (number of DMUs) optimization problems in each model.

Table 4. SBM-I (2013) scores, inefficiencies and slacks

\begin{tabular}{|c|c|c|c|c|c|c|c|}
\hline \multirow{2}{*}{ DMU } & \multirow{2}{*}{ Score } & \multicolumn{3}{|c|}{ Inefficiency } & \multicolumn{3}{|c|}{ Slack } \\
\hline & & K & $\mathbf{L}$ & $Y$ & K & $\mathbf{L}$ & $\mathbf{Y}$ \\
\hline Belgium & 0.926 & 0.053 & 0.021 & 0 & 92.0 & 190.1 & 0 \\
\hline Bulgaria & 0.453 & 0.171 & 0.376 & 0 & 25.0 & 2561.8 & 0 \\
\hline Czech Republic & 0.522 & 0.131 & 0.347 & 0 & 101.0 & 3569.3 & 0 \\
\hline Denmark & 1 & 0 & 0 & 0 & 0.0 & 0.0 & 0 \\
\hline Germany & 0.799 & 0.094 & 0.107 & 0 & 1374.3 & 8931.9 & 0 \\
\hline Estonia & 0.527 & 0.112 & 0.360 & 0 & 8.9 & 441.0 & 0 \\
\hline Ireland & 1 & 0 & 0 & 0 & 0.0 & 0.0 & 0 \\
\hline Greece & 0.537 & 0.236 & 0.227 & 0 & 343.3 & 1788.1 & 0 \\
\hline Spain & 0.648 & 0.208 & 0.144 & 0 & 1558.3 & 4951.4 & 0 \\
\hline France & 0.808 & 0.140 & 0.052 & 0 & 1682.2 & 2782.7 & 0 \\
\hline Italy & 0.720 & 0.153 & 0.127 & 0 & 1435.0 & 6167.2 & 0 \\
\hline Cyprus & 0.675 & 0.087 & 0.238 & 0 & 6.9 & 165.4 & 0 \\
\hline Latvia & 0.715 & 0.032 & 0.252 & 0 & 1.7 & 449.6 & 0 \\
\hline Lithuania & 0.774 & 0 & 0.226 & 0 & 0.0 & 585.0 & 0 \\
\hline Hungary & 0.687 & 0 & 0.313 & 0 & 0.0 & 2561.7 & 0 \\
\hline Malta & 1 & 0 & 0 & 0 & 0.0 & 0.0 & 0 \\
\hline Netherlands & 0.834 & 0.084 & 0.083 & 0 & 259.9 & 1420.9 & 0 \\
\hline Austria & 0.780 & 0.149 & 0.071 & 0 & 276.5 & 598.7 & 0 \\
\hline Poland & 0.722 & 0 & 0.278 & 0 & 0.0 & 8751.0 & 0 \\
\hline Portugal & 0.616 & 0.105 & 0.279 & 0 & 93.9 & 2501.2 & 0 \\
\hline Romania & 0.579 & 0.079 & 0.342 & 0 & 31.6 & 6349.4 & 0 \\
\hline Slovenia & 0.669 & 0.048 & 0.282 & 0 & 7.7 & 515.2 & 0 \\
\hline Slovakia & 0.818 & 0 & 0.182 & 0 & 0 & 800.8 & 0 \\
\hline Finland & 0.884 & 0.056 & 0.060 & 0 & 50.2 & 301.5 & 0 \\
\hline Sweden & 0.873 & 0.110 & 0.017 & 0 & 227.1 & 159.6 & 0 \\
\hline United Kingdom & 0.869 & 0.066 & 0.065 & 0 & 702.8 & 3875.4 & 0 \\
\hline
\end{tabular}

Source: own calculations based on European Commission (Ameco) and Eurostat.

Optimization problem formulated by (3.7) captures all sources of inefficiency of DMU under consideration. While we are interested in use of inputs, it may be useful to 
give the model input orientation to concentrate only on input use. Output slacks thus don't enter the objective function in (3.8) keeping nevertheless acting in the constraints. The results of the static SBM-I model are shown in the Table 4.

In the second column labeled "score", SBM measures of efficiency are presented. It is clear that there are three efficient DMUs (economies) - Denmark, Ireland, and Malta all achieving measures of efficiency equal unit. The three DMUs constitute efficiency (technology) frontier and define the empirical best practice of technical transformation. The other DMUs are performing under the frontier which is materialized in positive slack variables that define deviations from the potential. Recalling input orientation of the model, inefficiencies related to output should be zero. According to interpretation stated in the previous section, inefficiencies reported in the third and fourth columns ( $K$ and $L$ ) present penalties for non-zero slacks in corresponding inputs, thus the higher the value the more inefficiency is related to corresponding input. Having a look at V4 countries, it is obvious that labor use is excessive in all the four DMUs, in the Czech Republic in a less pronounced way since capital contributes to inefficiency as well. In general, SBM-I scores can be obtained by deducting sum of inefficiencies from unit, for example the Poland's score of 0.722 is equal 0.278 (labor inefficiency) subtracted from 1 . Slacks variables represent potential improvement in absolute values to reach the efficiency frontier, for Slovakia it would imply increase in number of employees by around 800.8 thousand (36.3\%). High relative labor slacks can be found for all the new member states of the EU. Intertemporal analysis was carried out based on the theoretical foundations given in the previous section and the results are given in Table 5. Taking a look at the SBM-I efficiency scores for 2000 (labeled as E1 in the second column), a comparison to 2013 scores reveals efficiency change over time defining thus catch-up term (C) of Malmquist index $\frac{d_{i}^{2}\left(x_{0}, y_{0}\right)^{2}}{d_{i}^{1}\left(x_{0}, y_{0}\right)^{1}}$ from (9).

As can be seen, SBM-I scores from Table 4 are acting as efficiency scores in the period 2 and are labeled E2 in Table 5. The catch-up is given by the ratio E2/E1 with the meaning of improvement (if bigger than unit) or worsening $(C<1)$ of individual performance of the country with respect to contemporary frontier. As for the catch-up in V4 countries, Slovakia improved its performance by $40 \%$ (in terms of SBM-I efficiency), less distinct was the improvement of Poland and the Czech Republic (10.2 and $16.8 \%$ respectively) and Hungary kept its score at an almost the same level of about 0.7. Malmquist index itself (M) is according to (3.9) given by a product of $C$ and frontier-shift effect $F$ reported in the fifth column. Efficiency change $C$ provides information on individual change of the "distance" to the new frontier of DMU performing now at the new level of input use and output production. It is clear that the efficiency frontier was in 2000 constituted by one more DMU (Latvia) which, however, did not achieved the unit score in the next period, nor did any other DMU except Denmark, Ireland, and Malta. Index $\mathrm{F}$ affecting overall productivity index appears to be lower than unit with the exception of Belgium, Ireland, and Sweden which implies no tangible improvement of technology over the period analyzed. For V4 the frontier-shift effect is quite near the unit which could be interpreted as keeping in touch with the prevailing technology.

Figure 2 depicts technological frontiers of the years 2000 and 2013. Since we assume constant returns to scale it is possible to plot capital and output per employee in two dimensional graph. The piecewise lines represent approximations of production 
Table 5. SBM-I $(2000,2013)$ scores, catch-up, frontier-shift and Malmquist index

\begin{tabular}{|c|c|c|c|c|c|}
\hline \multirow{2}{*}{ DMU } & \multirow{2}{*}{$\begin{array}{c}2000 \\
E 1\end{array}$} & \multirow{2}{*}{$\begin{array}{c}2013 \\
E 2\end{array}$} & \multicolumn{3}{|c|}{$2000-2013$} \\
\hline & & & C & $\mathbf{F}$ & M \\
\hline Belgium & 0.912 & 0.926 & 1.015 & 1 & 1.015 \\
\hline Bulgaria & 0.462 & 0.453 & 0.981 & 0.966 & 0.947 \\
\hline Czech Republic & 0.447 & 0.522 & 1.168 & 0.960 & 1.121 \\
\hline Denmark & 1 & 1 & 1 & 0.984 & 0.984 \\
\hline Germany & 0.759 & 0.799 & 1.053 & 0.991 & 1.043 \\
\hline Estonia & 0.596 & 0.527 & 0.885 & 0.966 & 0.855 \\
\hline Ireland & 1 & 1 & 1 & 1.031 & 1.031 \\
\hline Greece & 0.560 & 0.537 & 0.959 & 0.989 & 0.949 \\
\hline Spain & 0.679 & 0.648 & 0.955 & 0.994 & 0.949 \\
\hline France & 0.819 & 0.808 & 0.987 & 0.998 & 0.985 \\
\hline Italy & 0.800 & 0.720 & 0.899 & 0.994 & 0.894 \\
\hline Cyprus & 0.776 & 0.675 & 0.870 & 0.941 & 0.818 \\
\hline Latvia & 1 & 0.715 & 0.715 & 0.973 & 0.696 \\
\hline Lithuania & 0.648 & 0.774 & 1.194 & 0.787 & 0.939 \\
\hline Hungary & 0.695 & 0.687 & 0.989 & 0.951 & 0.941 \\
\hline Malta & 1 & 1 & 1 & 0.978 & 0.978 \\
\hline Netherlands & 0.831 & 0.834 & 1.003 & 0.991 & 0.994 \\
\hline Austria & 0.764 & 0.780 & 1.020 & 0.999 & 1.019 \\
\hline Poland & 0.655 & 0.722 & 1.102 & 0.958 & 1.055 \\
\hline Portugal & 0.650 & 0.616 & 0.948 & 0.967 & 0.917 \\
\hline Romania & 0.514 & 0.579 & 1.125 & 0.965 & 1.086 \\
\hline Slovenia & 0.732 & 0.669 & 0.914 & 0.951 & 0.869 \\
\hline Slovakia & 0.583 & 0.818 & 1.403 & 0.956 & 1.341 \\
\hline Finland & 0.843 & 0.884 & 1.049 & 0.991 & 1.039 \\
\hline Sweden & 0.777 & 0.873 & 1.123 & 1.004 & 1.128 \\
\hline United Kingdom & 0.842 & 0.869 & 1.032 & 0.990 & 1.022 \\
\hline
\end{tabular}

Source: own calculations based on European Commission (Ameco) and Eurostat.

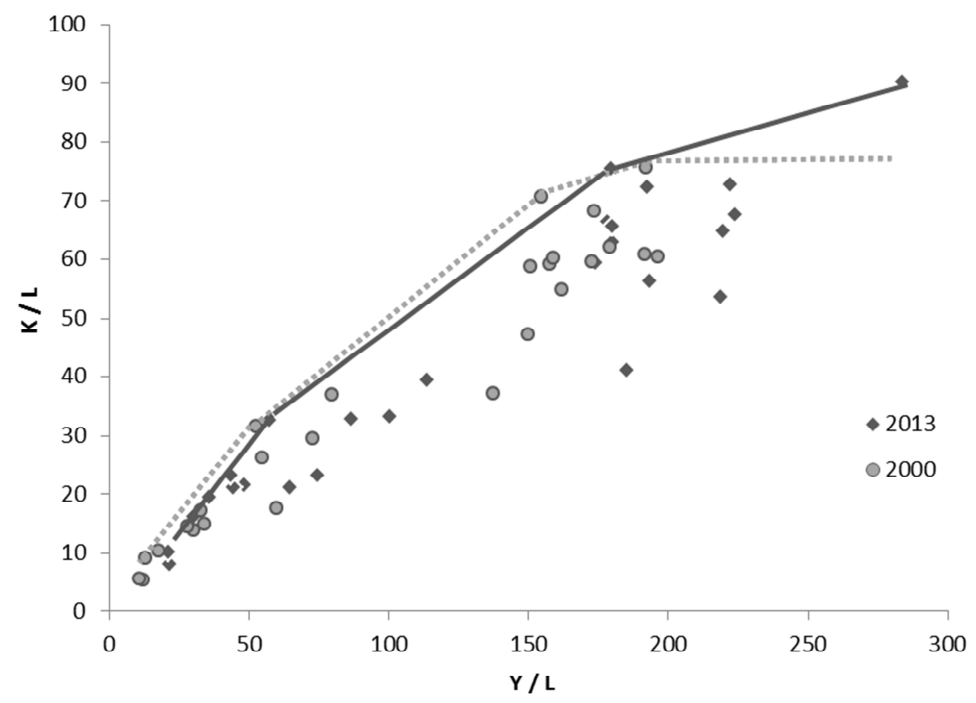

Figure 2. Empirical technological frontiers

Source: own calculations based on European Commission (Ameco) and Eurostat. 
possibilities sets corresponding to different periods. Activities of DMUs in 2000 and 2013 are distinguished. One can see four DMUs making up the frontier of 2000 and three of them constituting 2013 frontier. It is also apparent that there is no clear-cut shift of the frontier as has been deducted from the $\mathrm{F}$ close to unit. The frontier lines can be viewed as sets of benchmarks for inefficient units and can be therefore be interpreted as representing the best achievable technology of transforming inputs into outputs.

\section{CONCLUSIONS}

Applied to the Visegrad Four countries, productivity analysis can assist in answering the query whether the V4 still constitutes the most dynamic part of the EU as the Group has been believed to do over the whole decade following its EU entry. Based on CobbDouglas production function, an exercise on growth accounting reveals roles played by capital, labor, and technology change in the course of the Visegrad Group's economic development from 2000 onwards. The crisis slowed down FDI inflow as a main factor contributing to high economic growth which has reflected in lower catch-up rates. A decline has been also observed in all production factors growth as well as in total factor productivity.

The alternative non-parametric approach maintained the former results mainly in identifying no pronounced shift in empirical technology frontier constituted by EU countries. The main source of technical inefficiency in V4 was labor which is in line with findings regarding contributions to growth obtained by growth accounting. Qualitatively the poor TFP growth rates match with lower Malmquist indexes. Summarizing differences between V4 countries, despite the common drop in TFP in the after-crisis period, only Poland and Slovakia maintain its positive value. In Poland though, contribution of capital accounts for almost all of the growth. On the other hand, overly use of production factor labor identified by DEA, is a common feature of the group contributing to lower efficiency scores than in most developed European economies.

For decision-making, a more detailed results of calculations may be provided. For individual inefficient units, not only projections onto the frontier can be informative, it is also possible to determine a "peer group" consisting of efficient countries which make up a benchmark for the DMU under examination. Thus a closer attention may be drawn to examining successful policies of the best-practice countries identified.

At large, the results can be viewed as an empirical evidence of dynamics of the V4 economies within the European Union and the effect of the global crisis on European countries economic performance as well as a theoretical background for decisionmaking.

\section{REFERENCES}

Babunek, O. (2012). Foreign direct investment in visegrad four and the main trading partners. Statistika, 49(2), 14-26.

Barro, R.J. (1996). Determinants of economic growth: A cross-country empirical study. NBER Working Paper 5698WP 5698, National Bureau of Economic Research. National Bureau of Economic Research, 1996. Retrieved on March 15, 2014, from http://www.iedm.org/ uploaded/pdf/robertjbarro.pdf. 
Bijsterbosch, M., \& Kolasa, M. (2009). 'DI and productivity convergence in Central and Eastern Europe. An industry level investigation. European Central Bank Working Paper Series, No. 992 / January 2009.

Chang, Y.-T., Hyo-soo, P., Jeong, J., \& Lee, J. (2014). Evaluating economic and environmental efficiency of global airlines: A SBM-DEA approach. Transportation Research Part D Transport and Environment, 27, 46-50.

Charnes, A., Cooper, W.W. \& Rhodes, E. (1978). Measuring the efficiency of decision making units. European Journal of Operational Research vol. 2, 429-444.

European Commission (2009). Five years of an enlarged EU. Economic achievements and challenges. Retrieved on March 15, 2014, from http://ec.europa.eu/economy_finance/ publications/publication 14078_en.pdf.

European Commission (2008). Catching up, Growth and Convergence of the new Member States. Retrieved on March 15, 2014, from: <http://ec.europa.eu/economy_finance/publications/ publication7718_en .pdf.

European Commission (2009). Five years of an enlarged EU. Economic achievements and challenges. Available from http://ec.europa.eu/economy_finance/publications/publication 14078_en.pdf.

European Commission (2012). The 2012 Ageing Report. Economic and budgetary projections for the 27 EU Member States (2010-2060). Retrieved on March 15, 2014, from http://ec .europa.eu/economy_finance/publications/european_economy/2012/pdf/ee-2012-2_ en.pdf.

Eslami, R., \& Khoveyni M. (2014). Malmquist productivity index in several time periods. International Journal of Applied Operational Research, 4(1), 81-91.

Färe, R., Grosskopf, S., Norris, M., \& Zhang, Z. (1994). Productivity growth, technical progress, and efficiency change in industrialized countries. American Economic Review, 84, 66-83.

Farrell, M.J. (1957). The measurement of productive efficiency. Journal of Royal Statistical Society, III(120), 253-281.

Proietti, T., \& Musso, A. (2007). Growth accounting for the Euro area. A structural Approach. ECB Working Paper Series, No. 804, August 2007.

Romer, P. (1990). Endogenous technical change. Journal of Political Economy, 98, 71-102.

Schadler, S., Mody, A., Abiad, A., \& Leigh, D. (2006). Growth in the Central and Eastern European Countries of the European Union, IMF, Retrieved on March 15, 2014, from http://relooney .fatcow.com/00_New_1735.pdf.

Solow, R.M. (1957). Technical Change and the Aggregate Production Function. Review of Economics and Statistics, 39(3), 312-320

Tone, K. (2001). A slack-based measure of efficiency in data envelopment analysis. European Journal of Operational Research, 130, 498-509.

Tone, K. (2004). Malmquist Productivity Index: Efficiency Change Over Time. In W. Cooper, Seiford, L., \& Zhu, J. (Eds.), Handbook on Data Envelopment Analysis. Norwell, MA: Kluwer Academic Publishers.

Yörüka, B., \& Zaimb, O. (2005). Productivity growth in OECD countries: A comparison with Malmquist indices. Journal of Comparative Economics, 33(2), 401-420.

Witkowska, J. (2007). Direct investment in the changing business environment of the european union's new member states. Global Economy Journal, 7(4). 


\title{
Authors
}

\section{Eduard Nežinský}

Assistant professor at the Department of Applied Informatics and Computing Technology at the University of Economics in Bratislava (Slovakia).

\section{Elena Fifeková}

Assistant professor at the Department of Economic Policy at the University of Economics in Bratislava (Slovakia).

\author{
Correspondence to: \\ Ing. Eduard Nežinský, PhD \\ University of Economics in Bratislava \\ Faculty of National Economy \\ Department of Economic Policy \\ Dolnozemská cesta 1, 85325 Bratislava, Slovakia, \\ eduard.nezinsky@euba.sk
}


